\title{
Is Folate an Aetiological Factor for Colorectal Cancer Onset? A Case- Control Study
}

\author{
Asma Kassab ${ }^{1}$, Awatef Msolly ${ }^{1 *}$, Shunji Fujimori², Ramzi Lakhdar ${ }^{3}$ and Abdelhedi Miled ${ }^{1}$
}

${ }^{1}$ Biochemistry laboratory, Farhat Hached University Hospital, Sousse, Tunisia

${ }^{2}$ Department of Gastroenterology, Nippon Medical School, Graduate school of medicine, Tokyo, Japan

${ }^{3}$ Department of Biochemistry and Molecular Biology, Pharmaceutical Faculty, Monastir, Tunisia

\begin{abstract}
The aim of this study was to investigate the correlation of serum folate concentration in newly diagnosed patients with colorectal cancer. Patient population consisted of 101 sporadic colon cases, newly diagnosed, non-alcoholic and non-multivitamins users. Control population consisted of 130 healthy subjects. Venous blood was collected prior to the first chemotherapy intervention. Folate, vitamin B12 and homocysteine were measured using an automated analyzer system. Vitamin B6 was quantified using an enzyme immunoassay. Insulin and leptin were measured using immunoradiometric assay. Folic acid and vitamin B12 were significantly increased in cases compared to controls ( $15 \pm$ $7 \mathrm{ng} / \mathrm{ml}$ vs. $10 \pm 4 \mathrm{ng} / \mathrm{ml}, P=0.01 ; 330 \pm 200 \mathrm{pg} / \mathrm{ml}$ vs. $220 \pm 100 \mathrm{pg} / \mathrm{ml}, P=0.02)$ respectively. Folic acid and BMl were inversely correlated in controls $(r=-0.32 ; P=0.05)$. There was no significant difference of homocysteine and vitamin $B 6$ between cases and controls. Leptin and insulin were significantly higher in cases with BMI $\geq 27$ than in controls with $\mathrm{BMI} \geq 27(16 \pm 7 \mathrm{ng} / \mathrm{ml}$ vs. $14 \pm 7 \mathrm{ng} / \mathrm{ml} ; 32 \pm 18 \mu \mathrm{lU} / \mathrm{ml}$ vs. $29 \pm 11 \mu \mathrm{lU} / \mathrm{ml})$. However, stratifying leptin and insulin by cancer stages yielded to no clear pattern. Folate may be implicated as a potential aetiological factor for colorectal cancer.
\end{abstract}

Keywords: Colorectal cancer; Folate; Leptin; Insulin; Vitamin-B12

\section{Introduction}

Colorectal cancer (CRC) is the second most common malignant disease in developed countries, with 1 million new cases and 500000 deaths worldwide every year [1], and it is the third cancer type leading to death in both men and woman in industrialized countries [2]. In Tunisia $\mathrm{CRC}$ is the first cause of death in the digestive cancer which is drawing the public health researchers' attention. The absolute rate of colon cancer is being amplified by $5.3 \%$ (95\% CI: $+2.7 \%,+7,9 \%)$ in males and by $2.6 \%$ (95\% CI: $-0.1 \%,+5,1 \%)$ in females [3]. Therefore, major concerns must be provided in order to find out promoter factors and reduce the intensity of this disease on both the individual and the wider society.

Folate, as 5,10-methylene tetrahydrofolate, is an essential 1-C donor in DNA synthesis and, as 5-methyl tetrahydrofolate, in DNA methylation. The excess of 5,10-methylenetetrahydrofolate, promotes the methylation of deoxyuridine-5'-monophosphate (dUMP) to deoxythymidine-5'monophosphate (dTMP). 5-methyltetrahydrofolate, provides one carbon groups for the methylation of the amino acid homocysteine to methionine, a reaction in which vitamin B12 acts as a coenzyme. Methionine is the precursor to S-adenosylmethionine, the universal one carbon donor for methylation reactions, including DNA methylation. Since folate plays a substantial role in nucleotide synthesis, it was attributed in carcinogenesis action. Overwhelming consensus of epidemiologic evidence indicates that high folate status is associated with a reduced risk of CRC [4-9]. Paradoxically, a growing body of evidence suggests that high folate status is associated with an absolute risk of CRC [10-16]. The question, whether folate is CRC protector or promoter, has gained attention and has not been answered yet.

Obesity acts as an independent risk factor for malignant tumors of various organs including CRC [17]. The relative risk of CRC of obese patients is about 1.5 times higher than normal-weight individuals [18]. It is well known that leptin and insulin are associated with obesity. Several reports showed that leptin and insulin may act as CRC growth factors $[19,20]$. A meta-analysis showed that insulin therapy was positively associated with CRC risk [21]. However, recent studies showed the absence of associations between insulin, leptin and CRC risk [22]. Though leptin is secreted by adipocytes and cancerous tissue [20], the association between leptin levels and CRC risk has remained controversial.

The presence of controversial data relating several vitamins, hormones and $\mathrm{CRC}$ onset engaged us to investigate serum concentration of folate, vitamin B6, vitamin B12, homocysteine, insulin, and leptin in patients with CRC compared to healthy subjects. We also sought to establish the early involvement of folate in CRC onset.

\section{Materials and Methods}

\section{Study population}

Patient population consisted of 101 sporadic CRC cases who were admitted to department of medical oncology in Farhat Hached Hospital of Sousse (Tunisia). Patients' diagnoses were based on cancer histology confirmation. For this study, the inclusion was restricted to newly diagnosed, non alcoholic patients and non multivitamins users. The TNM staging system was used to describe patients' cancer stages.

Control population consisted of 130 healthy fasting volunteers belonging to the same socioeconomic group. Subjects with vitamin supplementation were excluded from the study. The study protocol was approved by the hospital ethical committee and informed consent was obtained from all subjects. An interviewer-administered questionnaire was completed about demographics, family history, and use of medication or supplements.

\section{Laboratory measurements}

Venous blood was collected prior to chemotherapy intervention.

*Corresponding author: Awatef Msolly, Dental faculty, Department of Biochemistry 5000 Monastir, Tunisia, Tel: 00216978671 55; E-mail: awatefmsolly@gmail.com

Received June 27, 2014; Accepted July 23, 2014; Published July 25, 2014

Citation: Kassab A, Msolly A, Fujimori S, Lakhdar R, Miled A (2014) Is Folate an Aetiological Factor for Colorectal Cancer Onset? A Case-Control Study. Med chem 4: 569-572. doi:10.4172/2161-0444.1000195

Copyright: $\odot 2014$ Kassab A, et al. This is an open-access article distributed under the terms of the Creative Commons Attribution License, which permits unrestricted use, distribution, and reproduction in any medium, provided the original author and source are credited. 
Blood samples were collected from all subjects after an overnight fast into tubes with EDTA as anticoagulant. The tubes were immediately placed on crushed ice, protected from light and centrifuged within 20 minutes at $2000 \mathrm{xg}$ for 10 minutes. Plasma samples were then stored at $-40^{\circ} \mathrm{C}$ until analysis.

Folate: 5-methyltetrahydrofolic acid was quantified using an automated analyzer system (AxSYM Abbott, Wiesbaden, Germany). The measure was based on an ion capture assay.

Homocysteine: Total homocysteine was estimated using an automated analyzer system (AxSYM Abbott, Wiesbaden, Germany). The measure was based on fluorescence polarization immunoassay technology.

Vitamin B6: Pyridoxal-5'-phosphate was quantified using an enzyme immunoassay (EIAab, Wuhan, China). The absorbance was measured at $450 \mathrm{~nm}$ using an ELISA microtiter plate reader (Tecan, Salzburg, Austria). Laboratory references were ranged between 0.5-30 $\mathrm{nmol} / \mathrm{l}$.

Vitamin B12: Cobalamin was quantified using an automated analyzer system (AxSYM Abbott, Wiesbaden, Germany). The measure was based on the microparticle enzyme immunoassay technology. Laboratory references were ranged between $40-900 \mathrm{pg} / \mathrm{ml}$.

Insulin: Insulin was assessed using sandwich immunoradiometric assay (Immunotech, Beckman coulter company, Prague, Czech Republic). The bound radioactivity was determined by gamma counter (PC-RIA.MAS, Stratec). Laboratory references were ranged between $5-100 \mu \mathrm{UI} / \mathrm{ml}$

Leptin: Leptin was assessed using radioimmunometric assay (Linco Research, USA). The bound radioactivity was determined by gamma counter (PC-RIA.MAS, Stratec). Laboratory references were ranged between $1-80 \mathrm{ng} / \mathrm{ml}$.

\section{Statistical analysis}

Statistical analysis was performed by the SPSS 18. Patients and controls were divided into groups stratified according to gender and $\mathrm{BMI}$ value as follows: $\mathrm{BMI} \leq 23,23>\mathrm{BMI}<27$ and $\mathrm{BMI} \geq 27$. KolmogorovSmirnov $\mathrm{Z}$ test was used to assess normality. For variables with normal distribution, Student $t$ test was used. For variables without normal distribution, Mann Whitney test was used. Differences between patients and controls, cancer stages and folate, cancer stages and leptin and cancer stages and insulin were assessed by independent samples t-test. Correlation between folic acid and BMI was estimated using Pearson's test. Data are expressed as mean value \pm SD. P-value $<0.05$ was considered to be significant.

\section{Results}

The average age was 48 years for controls and 56 years for patients (Table 1). Folic acid and vitamin B12 were significantly higher in patients compared to controls (Table 2). Folic acid and BMI were significantly inversely correlated in controls $(r=-0.32 ; \mathrm{P} \leq 0.05)$. Homocysteine and vitamin B6 differences between patients and controls were not significant. Leptin and insulin were significantly higher in patients with BMI $\geq 27 \mathrm{~kg} / \mathrm{m}^{2}$ than in controls with BMI $\geq 27 \mathrm{~kg} / \mathrm{m}^{2}$ (Table 3). When cases were stratified into groups according to folate, leptin and insulin, we found no significant difference in cancer stages.

\section{Discussion}

We reported here a significant increase of serum folate in colorectal incident cases compared to healthy controls ( $15 \mathrm{vs} 10 \mathrm{ng} / \mathrm{ml} ; \mathrm{P} \leq 0.05$ ). Epidemiological evidence revealed that high folate intake might enhance colorectal tumor recurrence and progression. One recent Meta-analysis data revealed that folic acid supplementary for 3 years had no effect on the adenoma recurrence while had an increased risk of adenoma lesion for those who received folic acid over 3 years [11]. An Aspirin/Folate Polyp Prevention Trial found an increased risk of advanced lesions with high malignant potential and an increased risk of having multiple adenomas among the folic acid supplementation group by providing folic acid for 6 years at $1 \mathrm{mg} /$ day [16]. In contrast, in two large prospective cohorts, the Nurses' Health Study and Health Professionals Follow-Up Study, higher pre-diagnostic levels of plasma folate were not associated with an increased risk of colorectal cancer specific or overall mortality [23]. It was reported that subjects with low plasma folate concentrations at baseline $(\leq 7.5 \mathrm{ng} / \mathrm{mL})$, supplemental folic acid decreased adenoma recurrence, whereas subjects with high folate concentrations at baseline $(>7.5 \mathrm{ng} / \mathrm{mL})$, supplemental folic acid had no significant effect [24]. A Japanese study found that patients with serum folate concentration greater than $8 \mathrm{ng} / \mathrm{ml}$ had the lowest risk of developing colorectal adenoma [25]. Multiple case-control and observational cohort studies suggest a reduction of $30 \%-40 \%$ in CRC risk for participants with high levels of folate intake compared to those with low levels [26]. According to some data [27], the risk of colorectal cancer decreases $11 \%$ for every $400 \mu \mathrm{g}$ of total folate ingested. A trial showed that folic acid supplementation at $5 \mathrm{mg} /$ day for 3 years in subjects with resected adenomas significantly reduced the number of recurrent adenomas [28]. Inconsistent results may due to polymorphism variations of folate metabolism enzymes. Genetic

\begin{tabular}{|c|c|c|}
\hline & $\begin{array}{l}\text { Cases } \\
n=101\end{array}$ & $\begin{array}{c}\text { Controls } \\
n=130\end{array}$ \\
\hline $\begin{array}{l}\text { Age, (years) } \\
\text { Females, } \mathrm{n}(\%) \\
\text { Males, } \mathrm{n}(\%) \\
\text { Diabetes, } \mathrm{n}(\%) \\
\text { Hypertension, n (\%) } \\
\text { alcohol } \\
\text { Positive family history, n (\%) }\end{array}$ & $\begin{array}{c}56 \pm 12 \\
63(61 \%) \\
38(38 \%) \\
16(15 \%) \\
26(25 \%) \\
-- \\
16(15 \%)\end{array}$ & $\begin{array}{c}48 \pm 7 \\
65(50 \%) \\
65(50 \%) \\
7(5 \%) \\
3(2 \%) \\
2(1 \%) \\
9(7 \%)\end{array}$ \\
\hline $\begin{array}{l}\text { Smoking, } \mathrm{n}(\%) \\
\text { Never } \\
\text { Past } \\
\text { Current }\end{array}$ & $\begin{array}{c}71(70 \%) \\
25(25 \%) \\
5(5 \%)\end{array}$ & $\begin{array}{c}104(80 \%) \\
13(10 \%) \\
13(10 \%)\end{array}$ \\
\hline $\begin{array}{c}\text { Body mass index, } \mathrm{n}(\%) \\
\mathrm{BMI} \leq 23 \\
23>\mathrm{BMI}<27 \\
\mathrm{BMI} \geq 27\end{array}$ & $\begin{array}{c}23(23 \%) \\
34(33.5 \%) \\
44(43.5 \%)\end{array}$ & $\begin{array}{l}56(43 \%) \\
52(40 \%) \\
22(17 \%)\end{array}$ \\
\hline $\begin{array}{l}\text { Cancer stages, n (\%) } \\
\text { Stage I } \\
\text { Stage II } \\
\text { Stage III } \\
\text { Stage IV }\end{array}$ & $\begin{array}{c}2(2 \%) \\
24(24 \%) \\
45(44 \%) \\
30(30 \%)\end{array}$ & \\
\hline
\end{tabular}

Table 1: Clinical data of incident colon cases and controls.

\begin{tabular}{|c|c|c|c|}
\hline & $\begin{array}{l}\text { Cases } \\
n=101\end{array}$ & $\begin{array}{c}\text { Controls } \\
n=130\end{array}$ & $\mathbf{P}$ \\
\hline Folate (ng/ml) & $\begin{array}{c}15 \pm 7 \\
17(10-25)\end{array}$ & $\begin{array}{c}10 \pm 4 \\
11(4-16)\end{array}$ & $0.01^{*}$ \\
\hline Leptin (ng/ml) & $\begin{array}{c}15 \pm 7 \\
16(3-24)\end{array}$ & $\begin{array}{c}14 \pm 8 \\
15(3-23)\end{array}$ & 0.1 \\
\hline Insulin $(\mu \mathrm{IU} / \mathrm{ml})$ & $\begin{array}{c}28 \pm 15 \\
30(10-46)\end{array}$ & $\begin{array}{c}27 \pm 19 \\
28(10-47)\end{array}$ & 0.2 \\
\hline Vitamin B12 (pg/ml) & $\begin{array}{c}330 \pm 200 \\
400(150-800)\end{array}$ & $\begin{array}{c}220 \pm 100 \\
250(200-600)\end{array}$ & $0.02^{*}$ \\
\hline Vitamin B6 (nmol/l) & $\begin{array}{c}10 \pm 4 \\
11(4-18)\end{array}$ & $\begin{array}{c}10 \pm 6 \\
10(6-20)\end{array}$ & 0.3 \\
\hline Homocysteine $(\mathrm{nmol} / \mathrm{ml})$ & $\begin{array}{c}10 \pm 5 \\
11(8-16)\end{array}$ & $\begin{array}{c}9.5 \pm 4 \\
10(8-14)\end{array}$ & 0.06 \\
\hline
\end{tabular}

Table 2: Serum parameters concentrations expressed in mean \pm SD and medians (interquartile ranges).

* Statistical significant difference 


\begin{tabular}{|c|c|c|c|c|c|c|c|c|c|c|c|}
\hline & \multicolumn{2}{|c|}{$\mathrm{n}$} & \multicolumn{2}{|c|}{ Folate $(\mathrm{ng} / \mathrm{ml})$} & \multirow[b]{2}{*}{$\mathrm{P}$} & \multicolumn{2}{|c|}{ Leptin (ng/ml) } & \multirow[b]{2}{*}{$\mathrm{P}$} & \multicolumn{2}{|c|}{ Insulin $(\mu \mathrm{IU} / \mathrm{ml})$} & \multirow[b]{2}{*}{$P$} \\
\hline & Cases & Controls & Cases & Controls & & Cases & Controls & & Cases & Controls & \\
\hline \multicolumn{12}{|l|}{ Females } \\
\hline All & 63 & 65 & $15,5 \pm 8$ & $10.3 \pm 5$ & $0.01^{*}$ & $13.4 \pm 6$ & $12 \pm 7$ & 0.06 & $29 \pm 17$ & $28 \pm 13$ & 0.2 \\
\hline $\mathrm{BMI} \leq 23$ & 15 & 33 & $15.3 \pm 9$ & $11 \pm 7$ & $0.01^{*}$ & $8 \pm 4$ & $7.5 \pm 4$ & 0.5 & $25 \pm 12$ & $25 \pm 11$ & 0.4 \\
\hline $23>\mathrm{BMI}<27$ & 19 & 20 & $14 \pm 7$ & $10.9 \pm 7$ & $0.01^{*}$ & $12.5 \pm 6$ & $12 \pm 5$ & 0.4 & $28 \pm 16$ & $28 \pm 9$ & 0.5 \\
\hline BMI>27 & 29 & 12 & $15 \pm 6$ & $10 \pm 4$ & $0.01^{*}$ & $16 \pm 8$ & $15 \pm 7$ & $0.05^{*}$ & $33 \pm 19$ & $30 \pm 12$ & $0.05^{*}$ \\
\hline \multicolumn{12}{|l|}{ Males } \\
\hline All & 38 & 65 & $14,8 \pm 6$ & $9.8 \pm 4$ & $0.01^{*}$ & $9.8 \pm 7$ & $9 \pm 5$ & 0.06 & $25 \pm 15$ & $24 \pm 12$ & 0.09 \\
\hline $\mathrm{BMI} \leq 23$ & 8 & 23 & $15 \pm 7$ & $10.1 \pm 6$ & $0.01^{*}$ & $5 \pm 3$ & $4 \pm 3$ & 0.08 & $23 \pm 10$ & $23 \pm 8$ & 0.3 \\
\hline $23>\mathrm{BM} \mid<27$ & 15 & 32 & $14.5 \pm 5$ & $10 \pm 5$ & $0.01^{*}$ & $8.5 \pm 6$ & $8 \pm 4$ & 0.1 & $24 \pm 15$ & $24 \pm 10$ & 0.3 \\
\hline $\mathrm{BMI}>27$ & 15 & 10 & $14 \pm 6$ & $9.6 \pm 3$ & $0.01^{*}$ & $11 \pm 6$ & $10 \pm 6$ & $0.01^{*}$ & $26 \pm 17$ & $25 \pm 11$ & $0.02^{*}$ \\
\hline All & 101 & 130 & $15 \pm 7$ & $10 \pm 4$ & $0.01^{*}$ & $15 \pm 7$ & $14 \pm 8$ & 0.1 & 2815 & $27 \pm 19$ & 0.2 \\
\hline $\mathrm{BMI} \leq 23$ & 23 & 56 & $15.3 \pm 7$ & $10.6 \pm 5$ & $0.01^{*}$ & $7 \pm 4$ & $6.2 \pm 4.5$ & 0.3 & $25 \pm 15$ & $25 \pm 10$ & 0.3 \\
\hline $23>\mathrm{BM}<27$ & 34 & 52 & $14.4 \pm 7$ & $10.5 \pm 6$ & $0.01^{*}$ & $11 \pm 6.5$ & $10 \pm 6$ & 0.2 & $27 \pm 14$ & $27 \pm 8$ & 0.3 \\
\hline $\mathrm{BMI} \geq 27$ & 44 & 22 & $14.8 \pm 6$ & $9.7 \pm 4$ & $0.01^{*}$ & $16 \pm 7$ & $14 \pm 7$ & $0.01^{*}$ & $32 \pm 18$ & $29 \pm 11$ & $0.05^{*}$ \\
\hline
\end{tabular}

Table 3: Folate, leptin, and insulin levels stratified by body mass index and gender.

* Statistical significant difference

variants in genes that play key roles in folate-associated one-carbon metabolism pathway have been investigated as potential colorectal adenoma susceptibility genes [29]. Aberrant DNA methylation of specific loci has been identified in the earliest precursor lesions for colon adenocarcinomas and aberrant crypt foci such as MINT1, MINT31, SLC5A8, and MGMT [30] and has been seen to drive the initiation and progression of colon cancer [31].

The increased plasma folate concentration in our non alcoholic patients, newly diagnosed and explored before carrying out their first chemotherapy provides evidence to folate supra-physiological concentrations in colon tumorigenesis. In fact, in order to assess the absolute involvement of folate in colon tumorigenesis we enrolled only newly diagnosed, non alcoholic patients. Blood samples were drawn before the first chemotherapy. Thus we eliminated factors (alcohol and chemotherapy molecules) interfering to folate metabolism. Alcohol is a folate antagonist that decreases its intestinal absorption and increases its excretion [32]. Moreover alcohol consumption was considered as CRC risk factor [33]. Blood samples were collected prior to chemotherapy in order to eliminate the interference of chemotherapy molecules such as leucovorin (LV, 5-formyltetrahydrofolate) which results in an approximately 2 -fold increase in methyltetrahydrofolate [34]. Moreover, in medical oncology department folinic acid is systematically injected within the cure to all colorectal incident cases. However, the role of folate supplementation during chemotherapy has been insufficiently explored [35].

The elevated homocysteine concentration in our patients may act synergistically with elevated folic acid in colorectal tumorigenesis. Elevated homocysteine may promote carcinogenesis through NF- $\kappa B$ activation and reactive oxygen species formation.

In this Tunisian study, mean serum folate concentration of $15 \mathrm{ng} /$ $\mathrm{ml}$ in patients and $10 \mathrm{ng} / \mathrm{ml}$ in controls is much higher than previous reports in other countries. US data from NHANES III which showed a mean folate concentration of $5.8 \mathrm{ng} / \mathrm{ml}$ in white American males and $7.2 \mathrm{ng} / \mathrm{ml}$ in white American females white American. White men had significantly higher folate concentration than did African American men or Mexican American men and white women had significantly higher concentration than did African American women or Mexican American women too, thus revealing differences in mean folate concentration among races [36]. High plasma folate found in our patients may reveal that Tunisian diet is 'naturally' rich in folate. In Tunisia, bread is considered as staple food which is prepared by flour imported from countries industrializing mandatory fortified folic acid flour in order to reduce the risk of neural tube defects in offspring $[37,38]$. The high serum folate concentration in Tunisian people might influence the results.

In this study, we reported a significant negative correlation between BMI value and serum folate concentration in controls. According to Kant plasma volume and tissue folate distribution are possible factors underlying the inverse association folate-BMI [39]. However, the majority of incident cases were overweight, obese, and had high serum folate concentration.

In this study, insulin was significantly elevated in cases with BMI $\geq 27 \mathrm{~kg} / \mathrm{m}^{2}$ compared to controls with BMI $\geq 27 \mathrm{~kg} / \mathrm{m}^{2}$. The data supported the previous reports [40]. Leptin was also significantly increased in cases with BMI $\geq 27 \mathrm{~kg} / \mathrm{m}^{2}$ compared to controls with BMI $\geq 27 \mathrm{~kg} / \mathrm{m}^{2}$. We expected to find statistical connection between obesity indexes and cancer stages. However, neither insulin nor leptin were correlated to CRC stages.

\section{Conclusions}

The high plasma folate concentrations in our prediagnostic and non-alcoholic patients may provide additional evidence to the impact of folate supra-physiological concentrations in colon tumorigenesis. Molecular investigations, to explain the inverse association between BMI and plasma folate concentrations, are warranted.

\section{Acknowledgment}

We wish to thank all contributors from the Department of Medical Oncology, Farhat Hached University Hospital, Sousse, Tunisia.

\section{References}

1. Quasar Collaborative Group, Gray R, Barnwell J, McConkey C, Hills RK, et al (2007) Adjuvant chemotherapy versus observation in patients with colorectal cancer: a randomised study. Lancet 370: 2020-2029.

2. Arnold CN, Goel A, Blum HE, Boland CR (2005) Molecular pathogenesis of colorectal cancer: implications for molecular diagnosis. Cancer 104: 2035 2047

3. Curado MP, Edwards B, Shin HR, Storm H, Ferlay J, et al. (2007) Cance Incidence in Five Continents. Lyon, IARC Scientific Publication 160: 107.

4. Lin YW, Wang JL, Chen HM, Zhang YJ, Lu R, et al. (2011) Folic acid supplementary reduce the incidence of adenocarcinoma in a mouse model of colorectal cancer: microarray gene expression profile. J Exp Clin Cancer Res 30: 116

5. Stevens VL, McCullough ML, Sun J, Jacobs EJ, Campbell PT, et al. (2011) High levels of folate from supplements and fortification are not associated with increased risk of colorectal cancer. Gastroenterology 141: 98-105, 105. 
Citation: Kassab A, Msolly A, Fujimori S, Lakhdar R, Miled A (2014) Is Folate an Aetiological Factor for Colorectal Cancer Onset? A Case-Control Study. Med chem 4: 569-572. doi:10.4172/2161-0444.1000195

6. Printz C (2011) Folate may help lower risk of colorectal cancer. Cancer 117: 5249.

7. Lee JE, Chan AT (2011) Fruit, vegetables, and folate: cultivating the evidence for cancer prevention. Gastroenterology 141: 16-20.

8. Gibson TM, Weinstein SJ, Pfeiffer RM, Hollenbeck AR, Subar AF, et al. (2011) Pre- and postfortification intake of folate and risk of colorectal cancer in a large prospective cohort study in the United States. Am J Clin Nutr 94: 1053-1062.

9. Kim DH, Smith-Warner SA, Spiegelman D, Yaun SS, Colditz GA, et al. (2010) Pooled analyses of 13 prospective cohort studies on folate intake and colon cancer. Cancer Causes Control 21: 1919-1930.

10. Sie KK, Medline A, van Weel J, Sohn KJ, Choi SW, et al. (2011) Effect of maternal and postweaning folic acid supplementation on colorectal cancer risk in the offspring. Gut 60: 1687-1694.

11. Fife J, Raniga S, Hider PN, Frizelle FA (2011) Folic acid supplementation and colorectal cancer risk: a meta-analysis. Colorectal Dis 13: 132-137.

12. Mason JB (2011) Unraveling the complex relationship between folate and cancer risk. Biofactors 37: 253-260.

13. Mullin GE (2011) Folate: is too much of a good thing harmful? Nutr Clin Pract 26: 84-87.

14. Lucock M, Yates Z (2009) Folic acid fortification: a double-edged sword. Curr Opin Clin Nutr Metab Care 12: 555-564.

15. Kim YI (2008) Folic acid supplementation and cancer risk: point. Cancer Epidemiol Biomarkers Prev 17: 2220-2225.

16. Cole BF, Baron JA, Sandler RS, Haile RW, Ahnen DJ et al. (2007) Polyp Prevention Study Group Folic acid for the prevention of colorectal adenomas: a randomized clinical trial. JAMA 297: 2351-2359.

17. Kim BC, Shin A, Hong CW, Sohn DK, Han KS, et al. (2012) Association of colorectal adenoma with components of metabolic syndrome. Cancer Causes Control 23: 727-735

18. Na SY, Myung SJ (2012) [Obesity and colorectal cancer]. Korean J Gastroenterol 59: 16-26.

19. Kaaks R, Toniolo P, Akhmedkhanov A, Lukanova A, Biessy C, et al. (2000) Serum C-peptide, insulin-like growth factor (IGF)-I, IGF-binding proteins, and colorectal cancer risk in women. J Natl Cancer Inst 92: 1592-1600.

20. Ferla R, Bonomi M, Otvos L Jr, Surmacz E (2011) Glioblastoma-derived leptin induces tube formation and growth of endothelial cells: comparison with VEGF effects. BMC Cancer 11: 303.

21. Berster JM, Göke B (2008) Type 2 diabetes mellitus as risk factor for colorectal cancer. Arch Physiol Biochem 114: 84-98.

22. Kabat GC, Kim MY, Strickler HD, Shikany JM, Lane D, et al. (2012) A longitudinal study of serum insulin and glucose levels in relation to colorectal cancer risk among postmenopausal women. Br J Cancer 106: 227-232.

23. Wolpin BM, Wei EK, Ng K, Meyerhardt JA, Chan JA, et al. (2008) Prediagnostic plasma folate and the risk of death in patients with colorectal cancer. $\mathrm{J}$ Clin Oncol 26: 3222-3228.
24. Wu K, Platz EA, Willett WC, Fuchs CS, Selhub J, et al. (2009) A randomized trial on folic acid supplementation and risk of recurrent colorectal adenoma. Am J Clin Nutr 90: 1623-1631.

25. Fujimori S, Gudis K, Takahashi Y, Kotoyori M, Tatsuguchi A, et al. (2011) Determination of the minimal essential serum folate concentration for reduced risk of colorectal adenoma. Clin Nutr 30: 653-658.

26. Kennedy DA, Stern SJ, Moretti M, Matok I, Sarkar M, et al. (2011) Folate intake and the risk of colorectal cancer: a systematic review and meta-analysis. Cancer Epidemiol 35: 2-10.

27. Hoekstra J, Verkaik-Kloosterman J, Rompelberg C, van Kranen H, Zeilmaker $M$, et al. (2008) Integrated risk-benefit analyses: method development with folic acid as example. Food Chem Toxicol 46: 893-909.

28. Jaszewski R, Misra S, Tobi M, Ullah N, Naumoff JA, et al. (2008) Folic acid supplementation inhibits recurrence of colorectal adenomas: a randomized chemoprevention trial. World J Gastroenterol 14: 4492-4498.

29. Nijhout HF, Reed MC, Ulrich CM (2008) Mathematical models of folatemediated one-carbon metabolism. Vitam Horm 79: 45-82.

30. Laird PW (2003) The power and the promise of DNA methylation markers. Nat Rev Cancer 3: 253-266.

31. Rashid A, Shen L, Morris JS, Issa JP, Hamilton SR (2001) CpG island methylation in colorectal adenomas. Am J Pathol 159: 1129-1135.

32. Mason JB, Choi SW (2005) Effects of alcohol on folate metabolism: implications for carcinogenesis. Alcohol 35: 235-241.

33. Ashktorab H, Begum R, Akhgar A, Smoot DT, Elbedawi M, et al. (2007) Folate status and risk of colorectal polyps in African Americans. Dig Dis Sci 52: 1462 1470.

34. Sadahiro S, Suzuki T, Maeda Y, Tanaka A, Ogoshi K, et al. (2010) Molecular determinants of folate levels after leucovorin administration in colorectal cancer. Cancer Chemother Pharmacol 65: 735-742.

35. Porcelli L, Assaraf YG, Azzariti A, Paradiso A, Jansen G, et al. (2011) The impact of folate status on the efficacy of colorectal cancer treatment. Curr Drug Metab 12: 975-984.

36. Ford ES, Bowman BA (1999) Serum and red blood cell folate concentrations, race, and education: findings from the third National Health and Nutrition Examination Survey. Am J Clin Nutr 69: 476-481.

37. Jacquet $F$ (1986) La Méditerranée: un marché privilégié pour le blé des EtatsUnis. Ed Montpellier CIHEAM-IAMM: 303-309.

38. Tunisie: Nouvelles importations de blé.s

39. Kant AK (2003) Interaction of body mass index and attempt to lose weight in a national sample of US adults: association with reported food and nutrient intake, and biomarkers. Eur J Clin Nutr 57: 249-259.

40. Chia VM, Newcomb PA, Lampe JW, White E, Mandelson MT, et al. (2007) Leptin concentrations, leptin receptor polymorphisms, and colorectal adenoma risk. Cancer Epidemiol Biomarkers Prev 16: 2697-2703. 